Kredo 3 (2020)
KREDO: Jurnal Ilmiah Bahasa dan Sastra
Terakreditasi Sinta 4 berdasarkan Keputusan Direktorat
Jenderal Penguatan Riset dan Pengembangan,
Kementerian Riset, Teknologi dan Pendidikan Tinggi
Republik Indonesia
Nomor: 23/E/KPT/2019. 08 Agustus 2019
https://jurnal.umk.ac.id/index.php/kredo/index

\title{
KONSTRUKSI GENDER PADA IDENTITAS PEREMPUAN DALAM NOVEL LARUNG KARYA AYU UTAMI
}

\author{
Maria Benga Geleuk ${ }^{1}$, Anindya Kusuma Wardani ${ }^{2}$ \\ Email: mariabengageleuk@gmail
}

Prodi Magister Kajian Sastra dan Budaya, Fakultas Ilmu Budaya Universitas Airlangga, Indonesia

Info Artikel Sejarah Artikel Diterima 22 Januari 2020 Disetujui 15 Mei 2020 Dipublikasikan 20 Mei 2020

\section{Keywords}

gender construction, identity, women, larung novel

\section{Kata Kunci}

konstruksi gender, identitas, perempuan novel larung
:

\section{Abstract}

Ayu Utami is a female writer who raises the lives of Indonesian women in her work. Critics who dissect Utami's works find that her work is related to women's politics, sexuality, and gender equality. Based on the research conducted, no one has ever mentioned the way women build their identity. Identity is important for women to determine their lives. Therefore, this study aims to examine the identities of the three female characters in the novel Larung by Ayu Utami. This research uses the descriptive qualitative method, which discusses the process of change and determines the identity of several female figures. The results showed changes in the identity of women, namely Yasmin, Cok, and Shakuntala. At first, they were increasingly interested in

: childhood. However, as they grow older, they think changes, becoming more critical of education and sexual relations. In addition, there are differences in identity shown by those three female figures in which they fight for their identity in the midst of patriarchal society according to their choice. Findings that prove there has been a change in the post-New Order era about women's identities. Women began to critically question their position in the community. Women also began to

: have the awareness to struggle and be free in determining their lives, both in education, work, and household.

\begin{abstract}
Abstrak
Ayu Utami merupakan pengarang yang seringkali mengangkat kehidupan para perempuan Indonesia dalam karyanya. Para kritikus yang membedah karya-karya Utami menemukan bahwa karyanya berhubungan dengan politik tubuh perempuan, seksualitas, dan kesetaraan gender. Berdasarkan penelitian yang dilakukan, belum pernah ada yang menyinggung cara perempuan membangun identitas mereka. Identitas merupakan hal penting bagi seorang perempuan dalam menentukan kehidupannya. Oleh karena itu, penelitian ini bertujuan untuk mengkaji identitas tiga tokoh perempuan dalam novel Larung karya Ayu Utami. Penelitian ini menggunakan metode kualitatif deskritif, yaitu menelusuri proses perubahan dan perbedaan identitas pada ketiga tokoh perempuan. Hasil penelitian menunjukan adanya perubahan identitas perempuan, yakni Yasmin, Cok, dan Shakuntala. Pada awalnya mereka mengalami ketertindasan di masa kanak-kanak. Akan tetapi, saat beranjak dewasa, pemikiran mereka berubah, yakni menjadi lebih kritis terhadap pendidikan dan hubungan seksual. Selain itu, ada perbedaan identitas yang ditunjukan oleh tiga tokoh perempuan. Mereka berani mengidentifikasi identitas mereka di tengah masyarakat patriarki sesuai dengan pilihan mereka. Temuan yang ada membuktikan bahwa telah terjadi pergeseran di masa pasca Orde Baru mengenai identitas perempuan. Perempuan mulai kritis mempertanyakan kedudukannya di tengah masyarakat. Perempuan juga mulai memiliki kesadaran untuk berani dan bebas dalam menentukan kehidupannya, baik dalam pendidikan, pekerjaan, dan rumah tangga.
\end{abstract}




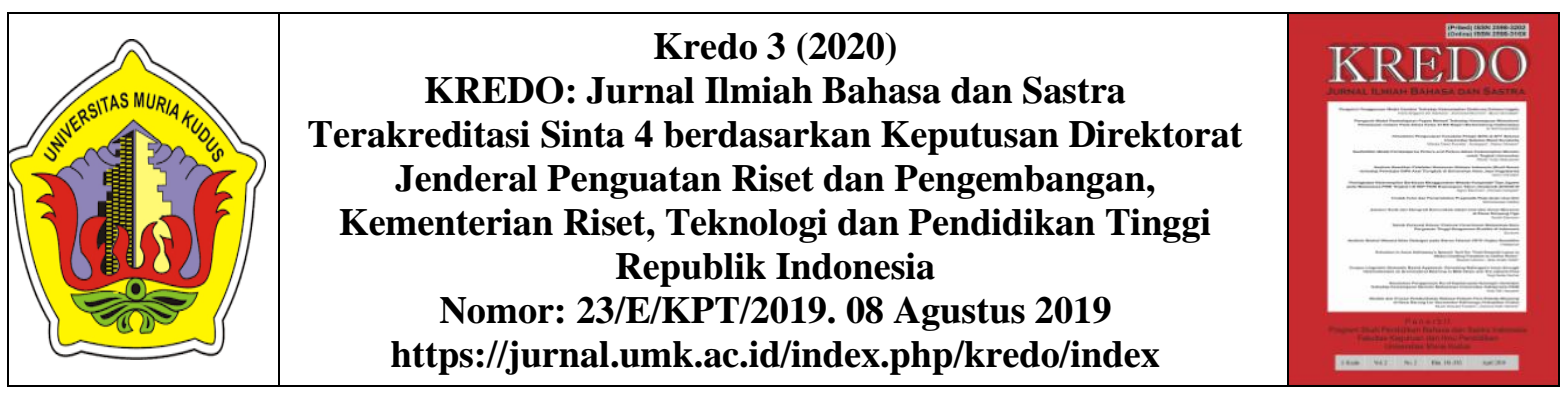

\section{PENDAHULUAN}

Fenomena dalam sastra seringkali mengangkat aktivitas kebudayaan atau sosial masyarakat tertentu. Bila menelusuri gejala yang muncul dalam karya sastra, maka kita secara langsung akan merefleksikan serta membandingkan kehidupan di dalam karya sastra dengan kehidupan nyata. Hal ini tidak dapat dipungkiri, sebab teks sastra merepresentasikan kehidupan sosial manusia.

Keberadaan sastra di tengah-tengah masyarakat yang demikian dapat dilihat dari peranannya. Sastra tidak hanya sebagai media hiburan atau pendidikan saja. Akan tetapi juga menjadi sarana pengarang dalam menyampaikan gagasan, pokok pikiran, dan ide-ide mengenai masalah sosial yang sedang berlangsung. Sebagaimana situasi yang terjadi akhir-akhir ini. Kehadiran teks sastra menjadi bagian menarik untuk dibahas karena membawa isu gender, yakni adanya kemunculan pengarang perempuan yang membangkitkan identitas perempuan. Goodman (Rokhmansyah, 2004:129-130; Geleuk, 2017:222) menyatakan bahwa sastra dapat digunakan sebagai media representasi budaya dan sosial dalam menjelaskan keterkaitan identitas gender, guna mengaspirasi keinginan, kebutuhan, dan hak perempuan. Sastra juga dipandang sebagai medium pengarang dalam mewujudkan perubahan sosial dengan menghadirkan kesadaran dan pengalaman perempuan melalui tulisan (Susanto, 2016:3).

Perempuan pengarang telah membuka babak baru dalam dunia sastra. Di mana mereka hadir dengan membawa warna baru melalui karyanya. Keseluruhan dari tulisan mereka menghadirkan identitas perempuan dengan deskripsi yang sangat berbeda. Sebagaimana yang kita ketahui sejak dulu pengarang laki-laki, maupun perempuan sendiri hanya menunjukan peran perempuan yang tidak begitu penting. Di mana tokoh perempuan hanya dijadikan objek dalam sebuah karya, baik dari kedudukannya sampai tubuhnya disalahartikan. Seperti halnya roman Siti Nurbaya karya Marah Rusli yang menghadirkan sosok perempuan bernama Siti Nurbaya. Ia digambarkan sebagai gadis yang penurut dan pasrah menikah dengan Datuk Maringgi, karena orang tuanya yang meminta. Dari cerita ini jelas perempuan tidak bisa mengambil keputusan untuk dirinya sendiri. Tidak dapat menentukan pilihan di hidupnya (Sugihastuti dan Soeharto, 2016). Pandangan perempuan sebagai objek di dalam karya sastra di atas sudah dianggap biasa dalam masyarakat, bahkan perempuan sendiri yakin akan kelemahannya dengan berpatok bahwa kelemahan itu disebabkan oleh tubuhnya.

Salah satu tokoh yang menganalisis penyebab ketertindasan perempuan adalah Simone de Beauvoir. Dalam pengamatannya, Ia melihat bahwa awal dari masalah tersebut terletak pada ketidakpercayaan perempuan dengan tubuhnya sendiri. Perempuan memandang diri sebagai makhluk lemah yang perlu dilindungi. Sebagai akibatnya, perempuan yakin bahwa ia tidak dapat hidup tanpa laki-laki dan dirinya adalah bagian lakilaki. Oleh sebab itu, dari tubuhnya perempuan diartikan dan dimanfaatkan melalui sudut pandang laki-laki, bukan dari perempuan sendiri. Dengan demikian, lakilaki menjadi subjek dan perempuan menjadi objek (de Beauvoir, 2016:43). Beauvoir menyangkal tindakan yang demikian. Ia menegaskan bahwa ketertindasan pada perempuan bukan karena tubuhnya. Akan tetapi, keidentitasan perempuan telah didefinisikan oleh masyarakat, bukan berasal dari dirinya 


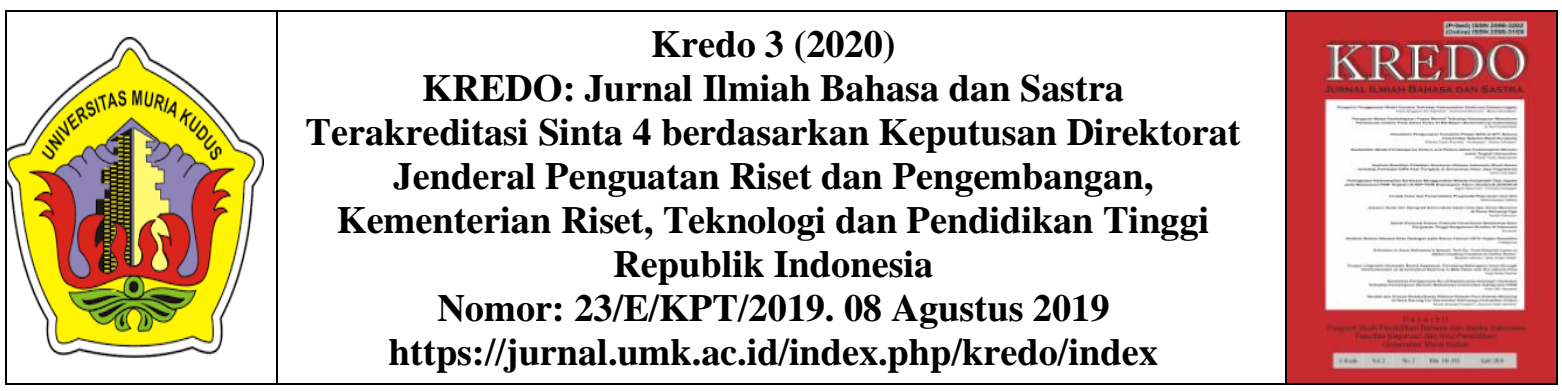

sendiri. Kemudian untuk mengabadikan definisi tentang identitas perempuan, maka diciptakanlah mitos-mitos agar perempuan percaya bahwa dirinya lemah dan kelas dua yang harus dilindungi (Tong, 2010).

Di antara banyak faktor pembentuk mitos, bisa disebutkan jika karya sastra adalah salah satunya. Banyaknya sastra yang berkembang dari zaman romantik sampai modern sengaja atau tidak ikut menetapkan mitos yang ada mengenai kelemahan tubuh perempuan. Perempuan dan tubuhnya tetap dijadikan objek di dalam karya sastra. Memasuki zaman postmodernisme, karya sastra mulai beralih. Di mana hal tidak penting dianggap penting, yang objek menjadi subjek. Begitu pula halnya peran perempuan dalam karya sastra ikut berubah. Hal ini ditandai dengan munculnya perempuan pengarang yang mengonstruksi identitas perempuan yang selama ini dianggap kurang pas. Dengan mengonstruksi ulang identitas perempuan ke dalam sebuah karya, maka ada kesempatan tokoh perempuan berproses menjadi dirinya. Melalui kajian identitas ini pula akan terlihat bahwa setiap orang memiliki identitas yang tidak esensi, namun dapat berubah-ubah sesuai keinginan. Sejalan dengan pemikiran tersebut, Hall (1990) menyatakan bahwa identitas bukan hal yang pasti dan abadi, namun berproses menjadi dan berkembang seiring waktu dan kesempatan.

Awal kemunculan kajian terhadap identitas ditandai dengan adanya gerakan sosial yang terjadi di Amerika Serikat pada tahun 1960-an seperti gerakan hak-hak sipil, gerakan kaum Negro, dan gerakan kaum perempuan. Tujuan dari gerakan yang dilakukan adalah untuk mendapatkan keadilan dan perlakuan yang sama dalam masyarakat, terutama dalam hal identitas mereka (Morissan, 2015:126). Identitas sangat dibutuhkan oleh setiap individu, salah satunya perempuan. Hal tersebut dilakukan guna mengenali dirinya terlebih untuk membedakannya dengan orang lain. Dengan adanya identitas, individu menjadi tahu siapa dirinya dan siapa orang lain yang ada di depannya, di mana ia berasal, dan seperti apa dia seharusnya.

Novel Larung (2017) karya Ayu Utami merupakan salah satu novel populer yang membawa angin segar untuk perempuan. Novel ini membicarakan kehidupan dan pengalaman perempuan pada masa pasca Orde Baru yang diwakili oleh tiga tokoh perempuan, yakni Yasmin, Cok, dan Shakuntala. Pada awal kemunculannya, novel Larung dianggap sebagai sesuatu yang kurang elok sebab di dalam novel, Utami mengungkapkan seks yang tabu dengan terus terang menjadi suatu yang sarat untuk diperbincangkan. Akan tetapi, melalui beberapa penelitian yang telah membahas karyanya. Ditemukan bahwa seks yang tabu itu, bila dimaknai mengandung kritik sosial terhadap keberadaan perempuan yang selalu diobjekan dalam hal tubuhnya dan hubungan seksual.

Penelitian tersebut dilakukan oleh Chasanah (2016) hasil penelitiannya menjelaskan bahwa tubuh perempuan dipakai sebagai politik yang menindas perempuan. Padahal, bila diperhatikan antara hubungan tubuh laki-laki dan perempuan, perempuanlah yang menuntun laki-laki dalam mengetahui fungsi genital miliknya. Hal inilah yang mematahkan pemahaman patriarki dan menjelaskan bahwa perempuan menjadi bagian yang sangat penting dalam proses hubungan tersebut. Sejalan dengan penelitian yang dilakukan oleh Chasanah, Menurut Prakoso dan Khasanah (2009) bahwa karya Ayu Utami salah satunya novel Larung telah membalikan apa yang selama ini diterima oleh kaum 


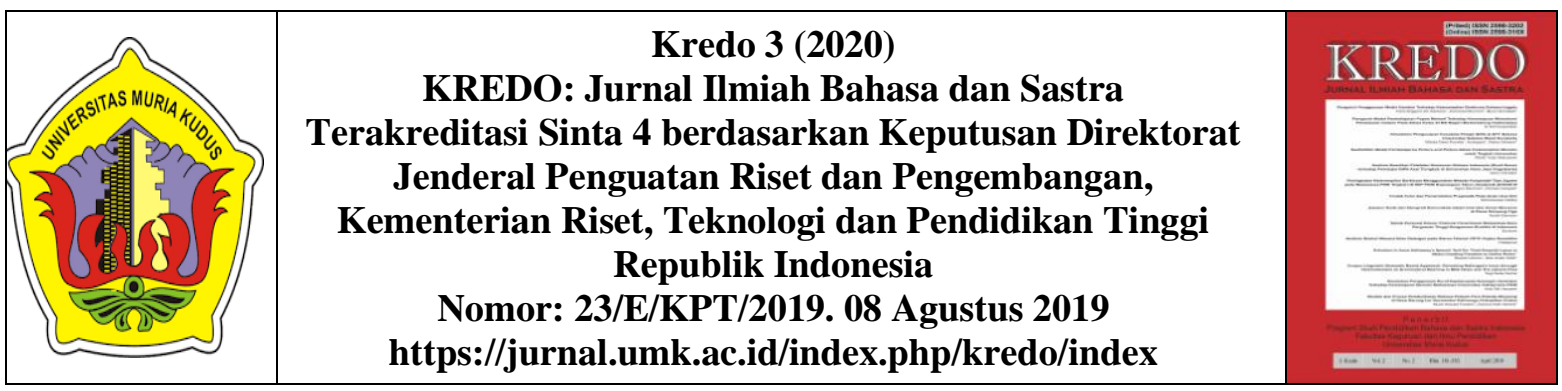

perempuan. Di mana sejak dulu perempuan cenderung dipaksa membaca dari sudut pandang kaum adam saja. Munculnya "tren" penulis perempuan dalam era 2000-an ini sebagai gerakan untuk menjawab bahwa perempuan pun dapat menuliskan bagian-bagian tubuhnya yang selama ini hanya dikuasai kaum laki-laki.

Selain itu, Purwanti (2009) juga menyebutkan bahwa novel Larung memperlihatkan adanya perjuangan dari perempuan untuk kesetaraan antara lakilaki dan perempuan. Tokoh-tokoh perempuan yang dihadirkan oleh pengarang pun menentang sistem patriarki melalui cara-cara yang cenderung radikal, yaitu heteroseksual atau lesbian. Tidak jauh berbeda dengan ketiga peneliti sesudahnya, Rengganis dan Pradopo (2005) menyampaikan bahwa perempuan dalam novel Larung mempunyai kemampuan untuk menjadi subjektivitas dengan menyuarakan seksualitasnya. Perempuan juga dapat mengubah budaya dan politik mengenai perempuan yang tersubordinat menjadi terbalik melalui konstruksi bahasa perempuan.

Berdasarkan penelitian yang telah dilakukan pada novel Larung karya Ayu Utami. Terlihat bahwa peneliti sebelumnya fokus pada politik tubuh perempuan, seksualitas, dan kesetaraan gender. Belum pernah ada peneliti yang menyinggung permasalahan identitas perempuan dalam karya Ayu Utami tersebut. Bagaimana cara dan proses perempuan membangun identitasnya di tengah masyarakat yang bersifat patriarki. Identitas itu merupakan hal penting bagi seorang perempuan dalam menentukan kehidupannya. Dengan begitu, Ia sadar akan keberadaannya dan menempatkan dirinya di tengah masyarakat sesuai pilihannya sendiri.
Oleh sebab itu, perlu adanya pembedahan mengenai proses perempuan dalam membangun identitasnya. Berdasarkan hal tersebut tujuan dari penelitian ini, yaitu mengkaji konstruksi gender pada identitas tokoh perempuan dalam novel Larung karya Ayu Utami.

\section{KAJIAN TEORI}

Penelitian ini memanfaatkan pendekatan identitas berspektif gender. Gender merupakan istilah yang merujuk pada pembedaan laki-laki dan perempuan berdasarkan pandangan sosial yang sudah dikontruksi. Laki-laki dan perempuan memiliki perbedaan secara kodrati atau bawaan sejak lahir. Misalnya anak laki-laki secara fisik lebih kuat, daripada anak perempuan. Hal-hal inilah yang kemudian telah membentuk pandangan masyarakat dan mengklasifikasikan ke dalam pembedaan ke wilayah peran, pekerjaan, sampai fungsi seorang laki-laki dan perempuan. Sejalan dengan pemikiran di atas, Puspitawati (2013) menyebutkan bahwa perbedaan peran gender telah melahirkan pembagian peran antara lakilaki dan perempuan dalam masyarakat. Gender ini juga yang telah melahirkan perbedaan tanggung jawab, bahkan ruang tempat di mana manusia beraktivitas.

Menurut Echols dan Shadily (1983:265) bahwa pengertian gender harus dibedakan dengan seks. Kebanyakan dari masyarakat menganggap bahwa gender dan seks adalah hal yang sama. Padahal kedua istilah ini sangat berbeda. Sebab gender lebih kepada tingkah laku seseorang yang mengidentifikasikan dirinya laki-laki atau perempuan.

Perdebatan mengenai gender sampai sekarang tetap menjadi bagian yang menarik. Hal ini dianggap bahwa sejarah 


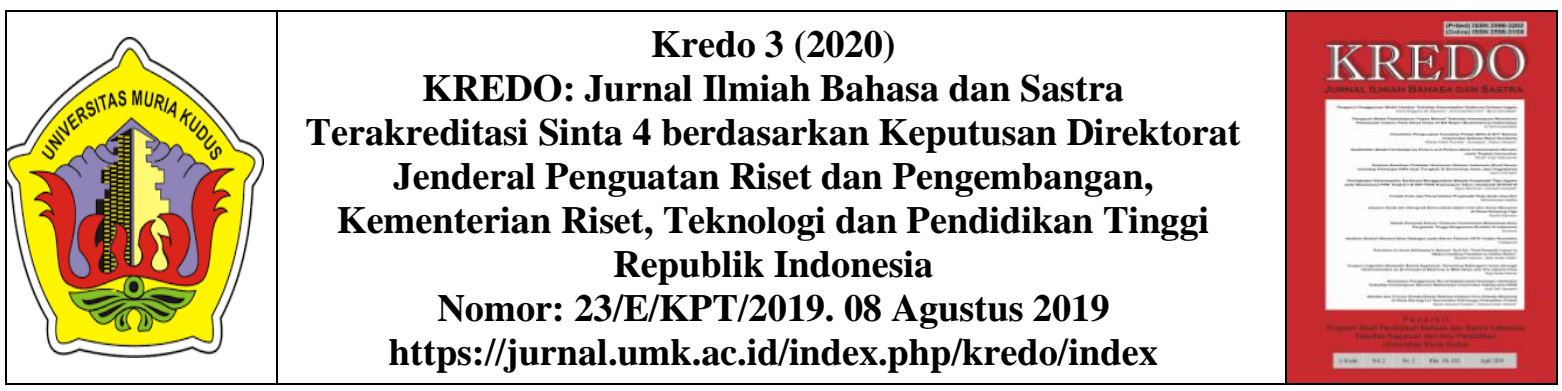

pembedaan gender telah menjadi suatu permasalahan di antara laki-laki dan perempuan. Melalui proses yang panjang, maka terbentuknya sejarah yang menentukan pembedaan laki-laki dan perempuan. Gender pada prakteknya, seringkali dikritik dan ditolak oleh kapitalisme. Hal ini dikarenakan, mereka tidak meyetujui sistem dan struktur yang telah mapan, apalagi mempertanyakan posisi dan identitas perempuan di dalam masyarakat (Fakih, 2016).

Pengertian gender yang demikian juga berhubungan erat dengan identitas, karena permasalahan yang sering muncul di dalam masyarakat adalah identitas gender. Keduanya saling berkaitan dalam hal menyangkut peran antara perempuan dan laki-laki. Pemaknaan identitas sendiri pada awalnya begitu samar. Identitas berdasarkan esensialisme dianggap tetap dan tidak berubah. Dapat dikatakan bahwa identitas setiap orang sudah ditentukan. Sebagaimana laki-laki dan perempuan telah memiliki identitas masing-masing. Pandangan yang menyatakan bahwa identitas sebagai kategori yang stabil dan tetap telah mendorong munculnya berbagai teori yang menekankan pada perbedaan. Para ahli mulai mengakui bahwa tidak ada karakterisik esensial yang dapat membedakan seluruh wanita atau seluruh laki-laki (Morissan, 2015:127).

Liliweri (2018:124) memandang bahwa telah terjadi perubahan dalam mengartikan identitas. Memasuki jaman postmodern yang lebih baru menunjukan bahwa identitas seseorang sering berubah dan mungkin mengandung kontradiksi yang cukup besar, misalnya arti maskulin dan feminim telah menjadi kurang jelas. Kemudian menurut para ahli post-modern sendiri ada beberapa faktor yang menyebabkan hal demikian. Pertama, setiap individu secara aktif menciptakan identitas sendiri. Kedua, individu memiliki banyak pilihan untuk mengikuti kelompok sosial mana yang akan dia ikuti. Ketiga, dalam hal kegiatan seperti belanja, konsumsi, dan lain sebagainya dapat membentuk dan mengubah identitas mereka. Oleh sebab itu, identitas dapat dikatakan tidak stabil, karena telah mengalami fragmentasi (Liliweri, 2018:143).

Barker membagi dua pengertian mengenai identitas dalam diri manusia, yakni identitas diri dan identitas sosial. Konsepsi yang diyakini tentang diri disebut identitas diri, sedangkan harapan dan pendapat orang lain dapat membentuk identitas sosial (Barker, 2009:173). Identitas dipandang sebagai hal yang personal sekaligus sosial. Melalui identitas, setiap orang akan mengetahui persamaan dan perbedaan dengan orang lain, baik dari aspek personal, sosial, dan bentuk-bentuk representasi. Dengan demikian, identitas bagi Barker bukan sebagai entitas yang tetap, melainkan deskripsi tentang diri.

Ada dua klasifikasi dalam teori identitas. Pertama, pandangan individu dalam mengonstruksikan berbagai kondisi di mana ia berada. Dalam hal ini individu memiliki banyak identitas yang saling tumpang tindih dan berubah, sehingga menghasilkan pandangan unik. Misalnya, pencampuran (intersection identities) yang terdapat pada ras, kelas sosial, jenis kelamin, serta orientasi seksual individu di antara segi identitas yang ada. Dengan demikian individu tidak perlu dipaksa untuk hanya memiliki satu identitas saja, namun ia bebas untuk menggunakan berbagai identitas menurut pilihannya. Kedua, identitas sebagai kategori yang saling berkaitan (interlocking identities), yaitu identitas yang berasal dari konstruksi yang ditawarkan dari berbagai kelompok sosial. Di mana kita menjadi bagian di 


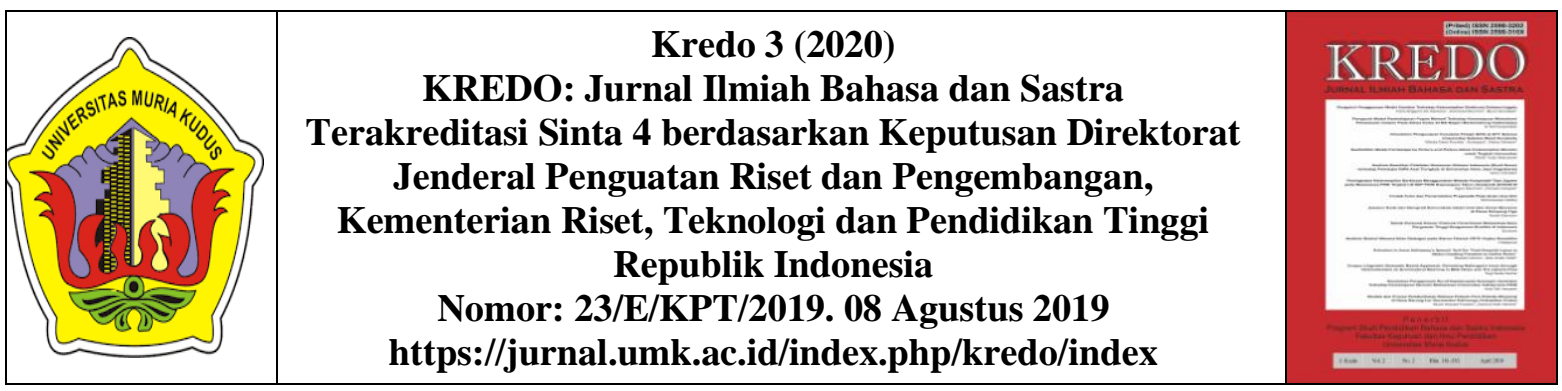

dalamnya seperti keluarga, komunitas, dan berbagai ideologi berpengaruh dan hasilnya menimbulkan perbedaan. Identitas ini dijalankan menurut atau berlawanan dengan norma-norma dan harapan dari pemilik identitas bersangkutan. Dengan demikian menunjukan bahwa identitas kita selalu berada dalam proses menjadi (Morissan, 2015:127-128).

Hellwig (2003) menggarisbawahi bahwa persoalan esensialisme identitas telah menjadi persoalan penting bagi gagasan mengenai perempuan. Feminitas bagi Hellwig menjadi suatu perdebatan yang dapat digali dengan teliti dan direpresentasikan sebagai persoalan zaman. Selanjutnya sebagai strategi yang bisa memberi perempuan semacam arah untuk memasuki ruang-ruang hidup yang lebih luas. Identitas perempuan masa kini tidaklah dibangun dari kualitas-kualitas tertentu yang esensialis, melainkan dari kemampuan perempuan untuk memetakan posisi dirinya dan kemudian merajut kualitas-kualitas tersebut sesuai dengan keinginannya.

\section{METODE}

Sumber data primer dalam penelitian ini adalah novel Larung (2017) karya Ayu Utami cetakan kelima. Sumber data sekunder dalam penelitian ini berasal dari beberapa buku dan artikel yang berhubungan dengan identitas gender. Teknik pengumpulan data menggunakan teknik pustaka, teknik baca, teknik simak, dan teknik catat. Pertama, membaca secara berulang-ulang novel yang berkaitan dengan proses pembentukan identitas perempuan. Kedua, menyimak dan mengidentifikasi konstruksi gender yang terjadi pada identitas tokoh perempuan yang dihadirkan melalui kata, kalimat, dan dialog. Ketiga, mencatat hasil identifikasi yang sudah didapatkan.

Setelah data didapatkan, maka selanjutnya dianalisis dengan menggunakan metode kualitatif berdasarkan deskritif, yaitu untuk memperoleh gambaran mengenai konstruksi gender pada identitas tiga tokoh perempuan di dalam cerita. Dalam tahap mengkaji ditelusuri proses pembentukan identitas yang terjadi, yaitu proses perubahan dan perbedaan identitas yang muncul pada tiga tokoh perempuan. Tahapan analisis berfokus pada identitas gender. Menurut Rokhmansyah (2016:7) identitas gender adalah pandangan seseorang, khususnya perempuan dalam menilai dirinya, kepribadiaannya, dan perilaku yang seharusnya ditampilkan sebagai perempuan. Selanjutnya dalam pembentukan identitas tidak terlepas pula oleh pengaruh lingkungan sekitar mengenai persepsi tentang dirinya.

\section{HASIL DAN PEMBAHASAN}

\section{Konstruksi Gender Pada Identitas Tokoh Perempuan}

Konstruksi gender yang terjadi pada identitas tokoh perempuan dianalisis berdasarkan letak perubahan dan perbedaan. Hal ini didasarkan bahwa antara identitas perempuan yang dipandang oleh masyarakat dengan identitas perempuan yang ada di dalam novel Larung terdapat perubahan dan perbedaan. Analisis ini dilihat, baik dari bentuk aktivitas, keinginan, pengalaman, dan kesempatan yang terjadi pada beberapa tokoh perempuan di dalam novel.

\section{Perubahan Identitas Perempuan (Intersection Identities) \\ Di dalam masyarakat identitas perempuan sudah ada dan ditetapkan.}




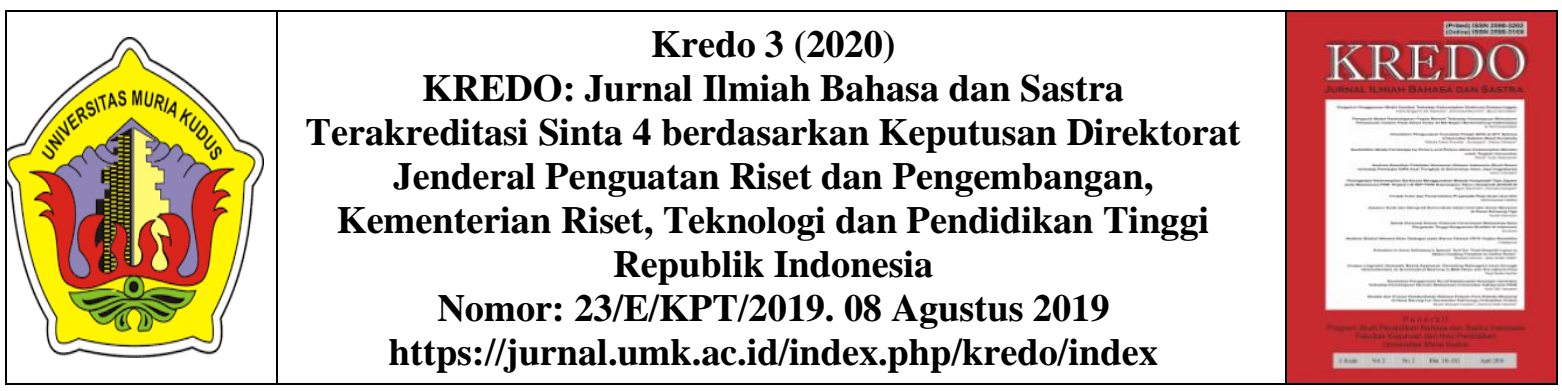

Sementara perempuan sendiri tidak pernah ikut atau diberi kesempatan untuk mendefinisikan dirinya sendiri. Perempuan menerima begitu saja identitas yang telah diberikan itu sebagai takdir yang harus dijalani. Akan tetapi, berbeda dengan identitas perempuan dalam novel Larung karya Ayu Utami yang menunjukan adanya perubahan dengan sangat jelas. Perubahan ini terjadi, karena ada proses pencampuran identitas sebelumnya pada tokoh perempuan.

Salah satu tokoh yang mengalami adanya perubahan identitas ialah Yasmin. Pada awal cerita, ketika masa kanak-kanak. Sosok Yasmin merasakan diri sebagai objek. Ia seperti anak perempuan pada umumnya, yaitu merasa malu bila memikirkan hubungan seksual. Baginya hal itu tabu, karena harusnya perempuan dinikmati bukan menikmati seksualitas. Namun saat itu ada dorongan di dalam dirinya untuk mengetahui lebih dalam mengenai seks itu apa. Dia juga terlihat suka memikirkannya dan membayangkan bila dirinya dapat menguasai hubungan seks. Dari norma yang ada di dalam masyarakat bahwa hubungan seksual harus dijauhi dari pikiran dan tindakan, apalagi dirinya masih anak-anak ketika itu. Yasmin membiarkan dirinya untuk mengikuti batasan tersebut, meskipun tidak sejalan dengan keinginannya.

Seks, yang belum sempat terdefinisikan waktu itu, berhubungan dengan kekerasan, penaklukan, dan rasa sakit. Dan itulah yang kubayangkan tentang laki-laki yang menarik.

Aku kehilangan sadisme kanakkanakku dan menjadi seperti protagonis dalam Histoire d'O, seorang gadis bernama $\mathrm{O}$, yang diserahkan oleh kekasihnya sendiri ke sebuah chateau untuk menjadi budak seks pria-pria (Utami, 2017:178-180).

Ketika beranjak dewasa, tokoh Yasmin mengalami perubahan sikap. Ia menyadari akan keobjekannya sejak kecil. Ia menganggap bahwa selama ini ia menghukum dirinya sendiri dengan berpandangan bahwa perempuan adalah wanita yang didominasi dan menempatkan dirinya sebagai objek. Dengan menyadari keobjekannya itu, Yasmin akhirnya memilih untuk menolak mengikuti arus yang sudah ditentukan oleh ajaran di dalam masyarakat bahwa hubungan seks didominasi laki-laki. Sebab baginya hal itu sama dengan menyakiti dirinya sendiri.

Lalu suatu pergeseran yang aneh terjadi. Adakah aku menghukum diriku sendiri, ataukah ini datang bersama masa awalku memasuki dunia patriakal yang tak kuketahui, dunia di luarku yang memaksa diri, di mana wanita adalah objek seksual? Aku kehilangan kesubyekan pada diriku dan menempatkan diri sebagai objek...

Apakah bedanya idealisme terhadap pengorbanan istri, poligami, dengan masokisme? Semuanya adalah interalisasi ketidakadilan (Utami, 2017:179-180).

Dari kutipan di atas terlihat tokoh perempuan di dalam novel mengeritisi nilai-nilai tentang perempuan di dalam masyarakat. Bahwasanya perempuan penurut, lemah, penyabar, sehingga perempuan mudah disakiti, kelas dua, dan perlu dilindungi. Tindakan Yasmin di dalam novel Larung mengubah stigma tentang perempuan. Di mana perempuan mempunyai keinginan yang yang sama 


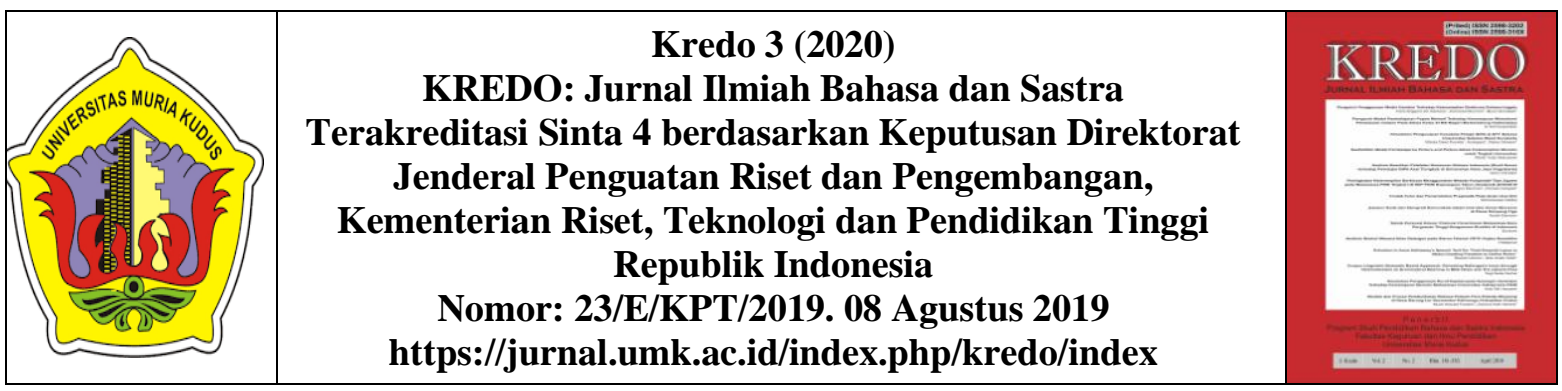

dengan laki-laki. Salah satunya dalam hubungan seks. Hal inilah yang kemudian dijelaskan oleh Sugihastuti dan Suharto (2016:61) bahwa jika perempuan sederajat seperti laki-laki, berarti perempuan mempunyai peluang untuk menentukan dirinya sendiri sebagaimana yang dipunyai oleh laki-laki selama ini, yakni persamaan hak di bidang sosial maupun budaya. Tokoh Yasmin juga digambarkan melalui sudut pandang tokoh lain sebagai yang mandiri, intelektual, dan tidak mudah ditipu.

Lihatlah temanku Yasmin
Moningka. Wanita sempurna
cantik, cerdas, kaya, beragama,
berpendidikan, setia pada suami.
Paling tidak itulah yang dia akui
tentang dirinya (Utami, 2017:88).

Kehadiran perempuan dalam novel Larung telah menggeser norma yang ada di dalam masyarakat. Perempuan yang pada awalnya di dalam masyarakat sebagai yang tertindas, baik dari faktor pendidikan sampai urusan rumah tangga telah berubah dengan menuculnya figur Yasmin. Ia telah membuktikan bahwa perempuan dapat setara dengan laki-laki dalam bidang pendidikan. Selain unggul dalam hal pendidikan, Yasmin juga mengalami pembentukan dari cara pandangnya mengenai hubungan seksual. Baginya hubungan seksual adalah keindahan bukan kewajiban.

Tapi sesungguhnya aku tidak begitu kontradiktif. Bawah sadarku cuma cerdik. Meski kecerdasan seringkali bukan mendamaikan, melainkan memisahkan. Yang membedakan aku dari wanita yang mengukuhkan patriaki adalah aku melokalisasinya pada fantasi seksual. Aku menerimanya dan melakukan seksualitas terhadapnya. Mereka menerimanya sebagai nilai moral, aku sebagai nilai estetik (Utami, 2017:181).

Narasi tersebut jelas melukiskan bahwa tokoh Yasmin dalam novel Larung memiliki identitas yang berubah, karena ia dapat mengubah sudut pandang identitas perempuan di dalam masyarakat. Dari paragraf yang berisi pikiran Yasmin tersebut jelas ia tidak hanya menyadarkan dirinya. Akan tetapi juga para perempuan yang tidak peduli akan keberadaaannya. Mereka menganggap dengan mengikuti ajaran yang sudah ditentukan oleh masyarakat, yaitu tunduk pada suami dan ikut melanggengkan dominasi patriaki, maka mereka menerima kebahagiaan. Padahal hal tersebut menjadi sesuatu yang abstrak, karena perempuan seakan-akan senang untuk disakiti dan tidak peduli pada keberadaannya.

Pemikiran dari tokoh Yasmin ini secara implisit menjelaskan bahwa perempuan bebas mengidentifikasi dirinya melalui sudut pandangnya. Tidak hanya itu, ia juga mengajarkan dirinya sendiri dan mengajak semua perempuan untuk memperjuangkan keidentitasnnya. Caranya yaitu dengan menolak kebiasaan yang ada di dalam masyarakat bahwa perempuan lemah dan tidak mampu membuat keputusan untuk hidupnya.

Serupa dengan perubahan identitas yang terjadi pada tokoh Yasmin. Cok juga mengalami perubahan pada dirinya. Akan tetapi, proses itu tidak dimulai saat dirinya masih kanak-kanak. Pemikirannya berubah ketika dia mulai merasakan jatuh cinta. Awalnya Cok digambarkan sebagai seorang perempuan yang mengikuti norma di dalam masyarakat. Salah satunya perempuan harus menjaga kesuciannya 


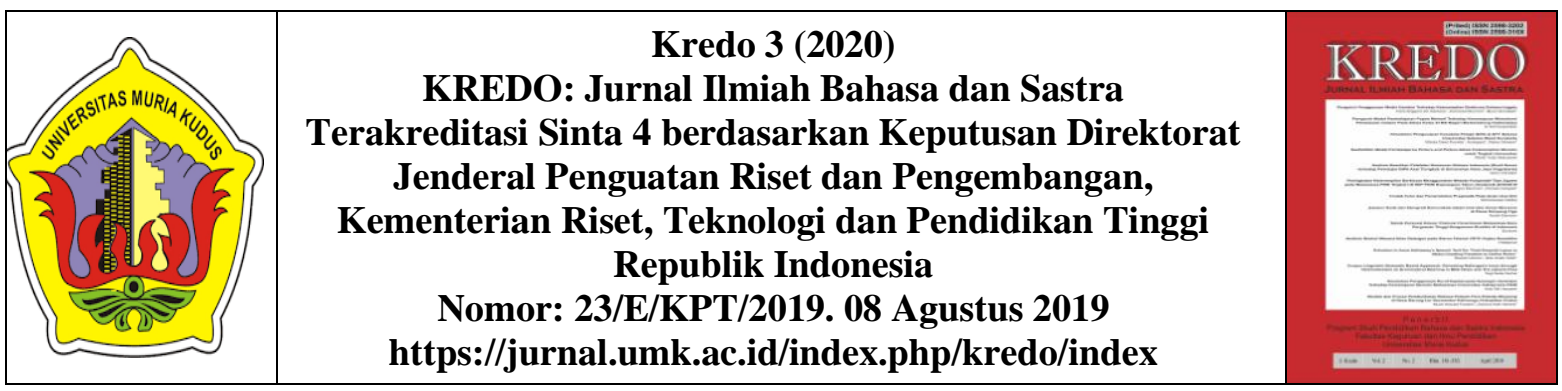

sampai menikah. Saat Cok menjalin hubungan dengan laki-lakipun, ia berusaha menjaga batasan-batasan tersebut. Namun perubahan pemikiran terjadi padanya. Dia merasa dengan melakukan hal tersebut hanya merugikan dirinya saja. Cok beranggapan hanya perempuan saja yang harus menjaga dirinya, sementara laki-laki tidak dipermasalahkan. Cok juga berpikir bahwa dalam hubungannya dengan setiap laki-laki yang ia kencani. Ia tidak bisa menikmati secara penuh, malah kekasihnya saja yang mendapatkan keutungan dari hubungan tersebut. Oleh sebab itu, ia memutuskan untuk melanggar norma yang ada, karena ia berpikir tidak perlu mengikuti apa yang ada di dalam masyarakat. Cok menganggap setiap perempuan memiliki karakteristik yang berbeda dan ia masuk dalam golongan perempuan penyuka seks secara terbuka.

Kami pemuja eros. Aku memang liar. Tapi apa boleh buat. Kupikir begitulah aku ditakdirkan. Semua orang diciptakan dengan karakter masing-masing sebagaimana garis tangan ditentukan saling berbeda (Utami, 2017:90).

Lalu kupikir-pikir, kenapa aku harus menderita untuk menjaga selaput daraku sementara pacarku mendapat kenikmatan? Enak di dia engga enak di gue. Akhirnya kupikir bodo amat, ah, udah tanggung (Utami, 2017:93).

Berdasarkan penggalan isi cerita di atas menunjukan bahwa Cok tidak khawatir dengan perbuatannya yang telah melanggar norma di dalam masyarakat. Ia tidak takut, bila identitas keperempuaannya dicap buruk. Hal ini disebabkan adanya keyakinan dalam diri Cok yang menganggap bahwa setiap perempuan dapat berubah sesuai dengan pemikirannya. Jadi identitas perempuan tidak dapat diberikan oleh masyarakat, karena perempuan akan berproses sebagaimana ia harapkan. Selain itu, tokoh Cok di sini secara tidak langsung juga mengeritik aturan yang dibuat oleh masyarakat bahwa perempuan harus menjaga keperawanannya, sementara lakilaki tidak perlu mengkhawatirkan hal tersebut. Adanya perbedaan pemberian tanggung jawab ini yang secara tidak langsung menyudutkan identitas perempuan, bila sampai melanggar aturan tersebut.

Selain Yasmin dan Cok. Tokoh perempuan yang mengalami perubahan pemikiran adalah Shakuntala. Pembentukan identitas pada diri Shakuntala disebabkan adanya ketertarikan dirinya pada tubuh dan peran laki-laki (Heteroseksual). Hal ini berawal saat dia masih kecil. Di dalam kisah disampikan bahwa Shakuntala memiliki kakak laki-laki yang lebih dibanggakan dalam setiap hal. Setiap ingin mencoba melakukan hal serupa dengan tindakan yang dilakukan oleh kakaknya. Ia dihentikan oleh ayahnya, karena ayahnya beranggapan bahwa Shakuntala sebagai anak perempuan pasti lemah dan tidak sanggup melakukan pekerjaan tersebut. Diam-diam ia merasa iri dengan perhatian lebih yang diberikan kedua orang tuanya kepada kakaknya, karena kakaknya terlahir sebagai laki-laki. Oleh sebab itu, dalam proses membangun identitas, Shakuntala melihat dirinya tidak hanya sebagai sosok perempuan, tetapi juga hadir sosok laki-laki. Ia membuktikan dirinya juga bisa melakukan sebagaimana yang dilakukan oleh kakaknya dengan perubahan sikapnya yang cenderung ke sisi maskulin. Ia merasa tubuhnya kuat dan mampu melakukan pekerjaan yang dilakukan oleh laki-laki. Hal-hal inilah 


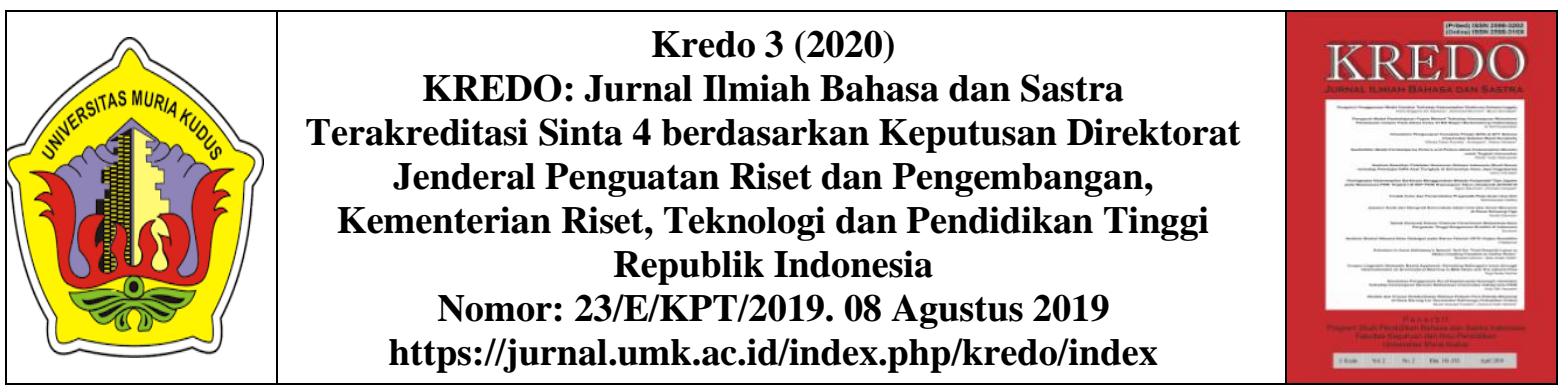

yang mendorong Shakuntala dalam proses mencari jati dirinya.

Namaku hanya satu: Shakuntala.

Tapi sering aku merasa ada dua dalam diriku. Seorang perempuan, seorang lelaki, yang saling berbagi sebuah nama yang tak mereka pilih.

Aku mempunyai kakak lelaki. Orangtuaku percaya bahwa pria cenderng rasional dan wanita emosional. Karena itu pria akan memimpin dan wanita mengasihi. Maka Bapak mengajari abangku menggunakan akal untuk mengontrol dunia, juga badan. Aku tak pernah dipaksanya untuk hal yang sama, sebab ia percaya pada hakikatnya aku tak mampu (Utami, 2017:154).

Dari sudut pandang tokoh Shakuntala mengenai dirinya membuktikan bahwa identitas itu tidak stabil. Setiap perempuan tidak selamanya memiliki sisi feminin, begitupula laki-laki tidak seterusnya memiliki sisi maskulin. Sebagaimana yang digambarkan oleh tokoh Shakuntala bahwa ia tidak dapat menjadi feminim saja, tetapi ia merasa ada sisi maskulin juga di dalam dirinya dan keduanya saling membaur. Semua hal yang ia rasa dan alami dalam proses perubahan tersebut sebagai sesuatu yang wajar bagi dirinya. Hal ini dikarenakan ada dorongan dan kesempatan bagi dirinya untuk mendefinisikan seperti apa yang ia mau. Selain itu, penceritaan dari kehidupan masa kecil Shakuntala juga merupakan sindiran bahwa masih banyak orang tua yang lebih bangga memiliki anak laki-laki, daripada anak perempuan.

\section{Perbedaan Identitas Perempuan (Interlocking Identities)}

Perbedaan identitas perempuan di dalam novel Larung terjadi pada tiga tokoh perempuan, yakni Cok, Shakuntala, dan Yasmin. Perbedaaan identitas ini akibat dari keterkaitan antara proses pencampuran dalam perubahan identitas. Perbedaan identitas terbentuk dari kelompok sosial di mana mereka menjadi bagian di dalamnya. Identitas perempuan dapat berjalan sesuai ketentuan norma dan nilai di dalam masyarakat atau malah ada penolakan yang terjadi karena tidak sesuai harapan dari pemilik identitas.

Tiga tokoh perempuan, yakni Yasmin, Cok, dan Shakuntala menunjukan bahwa setiap perempuan memiliki perbedaan identitas. Hal ini terlihat dari penolakan mereka terhadap aturan yang dibuat dalam masyarakat mengenai identitas perempuan. Dapat dikatakan bahwa mereka tidak mengikuti sepenuhnya norma dan nilai yang ada. Mereka sendiri yang memutuskan baik dan buruknya kehidupan mereka.

Seperti tokoh Cok yang berpikiran bahwa kehidupan tidak adil pada dirinya, karena ia seorang perempuan. Di mana ia merasakan bahwa perempuan selalu dijadikan objek dan pria sebagai subjek. Dia juga menyindir streotipe yang melekat pada perempuan bahwa keputusan yang diambil oleh perempuan selalu dianggap salah. Anggapan negatif demikian juga ikut dibenarkan oleh kebanyakan perempuan sendiri. Oleh sebab itu, Cok menjalani kehidupannya sesuai dengan keinginannya. Dia tidak ingin mengikuti apa yang sudah menjadi ketetapan masyarakat mengenai seorang perempuan yang harus menjaga diri ataupun menjaga keperawanan. Cok memutuskan memiliki sifat yang berlainan dengan perempuan pada umumnya. Ia suka berganti-ganti pasangan, namun ia jujur melakukan hal tersebut dan tidak khawatir dipandang sebagai perempuan yang tidak baik. 


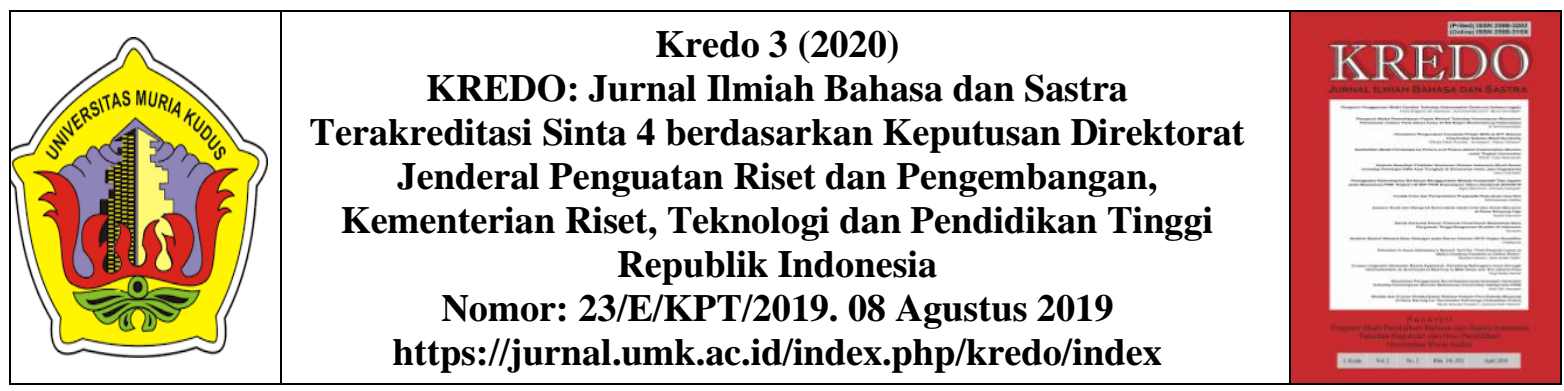

Perempuan eksperimen. Bayangkan! Semua akan mengartikannya perempuan untuk eksperimen. Seperti kelinci percobaan, kelinci buat percobaan. Kadang aku jengkel, apapun yang kita lakukan, yang juga dilakukan laki-laki, kok kita mendapat cap jelek. Laki-laki tidur bergantian dengan banyak cewek akan dicap jagoan. Arjuna. Tapi perempuan yang tidur dengan banyak laki-laki dibilang piala bergilir. Pelacur. Apapun yang kita lakukan selalu dianggap objek. Bahkan oleh sesama perempuan (Utami, 2017:94-95).

Biarin. Paling tidak, aku bisa menyombong bahwa akulah satusatunya dari kami berempat yang pertama kali melakukan hubungan seks karena sadar dan suka (Utami, 2017:97).

Berdasarkan kutipan tersebut terlihat bahwa tokoh Cok dideskripsikan memiliki sifat jujur dan selalu kritis. Ia seringkali mempertanyakan ketidakadilan terhadap perempuan di masyarakat. Hal ini dikarenakan ia memiliki kesadaran bahwa dirinya mengalami ketertindasan. Banyak perempuan yang memiliki kesadaran, namun diam saja akan ketertindasan yang didapatkan. Kebanyakan perempuan berpikir bahwa perlakuan tersebut sudah biasa dan menerimanya sebagai identitas. Akan tetapi, tokoh Cok ingin membuktikan bahwa identitas perempuan bisa berubah sesuai dengan pilihan yang diambil oleh individu tersebut.

Pemikiran dari Cok ini juga tidak terlepas dari lingkungan sekitar. Di mana ia berproses dalam hidupnya. Awalnya ia malu, bila ketahuan suka ganti-ganti pasangan. Melalui pengalamannya saat memiliki hubungan dengan laki-laki. Ia sadar bahwa ia juga bisa menguasai lakilaki. Dorongan ini semakin kuat saat Cok menjalin pertemanan dengan Yasmin dan Shankuntala. Secara tidak langsung mereka juga membentuk rasa percaya diri Cok, sehingga ia to the point saat menceritakan bahwa dirinya suka berganti-ganti pasangan.

Tokoh Cok juga merefleksikan bahwa perempuan secara seks dapat mendominasi laki-laki. Bila kita membicarakan permasalahan seks di dalam masyarakat, laki-lakilah yang lebih terlihat mendominasi dalam hubungan seksual. Hal ini berbeda dengan identitas perempuan yang ada di dalam novel Larung. Perempuan juga dapat mendominasi dalam menjalin hubungan seksual. Dengan demikian, tokoh perempuan yang diperankan oleh Cok membuktikan bahwa identitas perempuan selalu berubah. Sejalan dengan penggambaran dari isi cerita tersebut, Hasyim (2016:38) berpendapat bahwa identitas yang melekat pada individu tidaklah satu identitas. Melainkan banyak identitas. Hal ini ditegaskan melalui penggalan teks di dalam novel.

"Manusia tidak terdiri dari satu," kataku. Aku tahu ada sosok lain dalam teman-temanku yang aku bisa lihat, sebagaimana diriku lain yang tak mereka ketahui. Kawan-kawanku berbeda satu sama lain. Kawankawanku: ketiganya dengan identitasnya satu-satu. Tapi, jika saja teman-temanku berputar secepat gasing, mereka akan menemukan mahluk lain dari dari tubuh masingmasing (Utami, 2017:152-153).

Dari monolog dalam novel Larung memperlihatkan tokoh Shakuntala yang mendeskripsikan dirinya sebagai perempuan. Ia meyakini identitas dirinya 


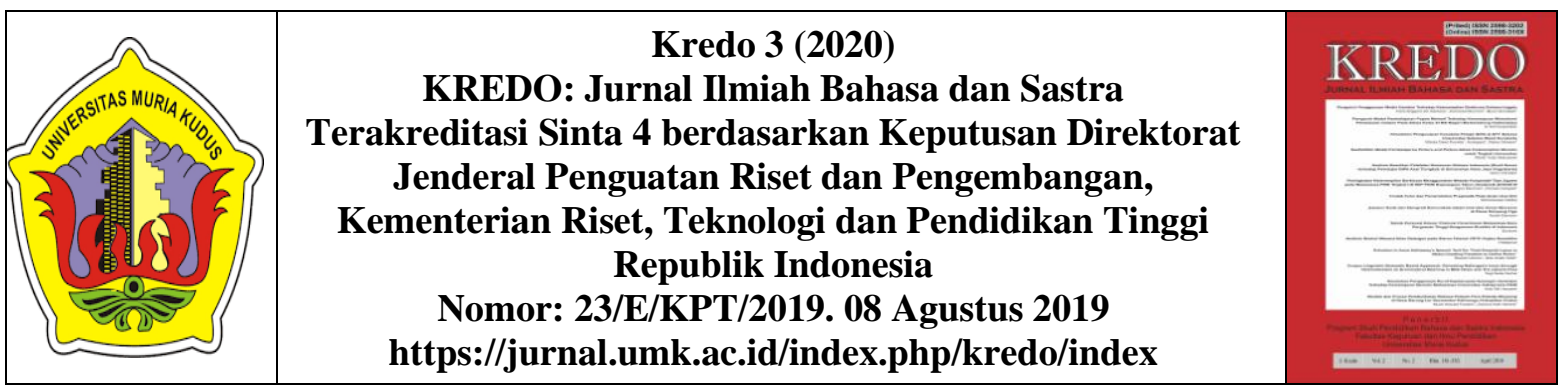

yang berubah-ubah. Ia juga meyakini bahwa semua orang tidak hanya memiliki satu identitas. Manusia bagi dirinya akan berubah sesuai dengan situasi kehidupan. Di mana ia hidup, dengan siapa ia sering bertemu, sampai cara ia memperlakukan orang lain akan berbeda. Hal ini dilihat oleh tokoh Shakuntala sebagai hal yang wajar. Perbedaan Shakuntala dengan perempuan pada umumnya didorong dari komunitas yang membentuknya. Sebagai seorang penari, ia seringkali berperan sebagai tokoh laki-laki. Di mana ia merasa bahwa jiwa kelaki-lakinya keluar dari dalam tubuh dan ia membiarkannya. Sebab bagi dirinya dia bukan hanya seorang perempuan, tetapi juga ada sisi laki-laki di dalam dirinya. Hal itu tidak ia khawatirkan, karena ia menganggap identitas setiap orang tidak terdiri dari satu sebagaimana yang dipikirkan oleh banyak orang.

Suatu malam, ketika aku duduk dalam sebuah ruang dan mengagumi dia menyanyi tanpa penggiring, lelaki dalam diriku muncul dari belakang tubuhku seperti energi yang lepas. Aku tidak bicara dengannya tetapi si pesinden melihatnya lalu mereka menembang bersama. Lalu mereka berdekatan. Mereka melepas kain masing-masing dan saling berdekatan. Setelah itu mereka saling berkata, "Betapa indahnya. Kita sama-sama punya payudara (Utami, 2017:168-169).

Dari kutipan tersebut menegaskan bahwa perempuan tidak selamanya memiliki sifat yang lemah lembut sebagaimana yang dikatakan oleh masyarakat. Shakuntala merasa dirinya sebagai subjek sebab dia melakukan apa yang dia mau. Begitu pula ketika ia memiliki banyak identitas, ia merasa bebas menentukan pilihannya. Hanya objek saja yang tidak berubah, karena objek diatur oleh subjek. Dengan demikian secara tidak langsung, tokoh Shakuntala mengeritik anggapan bahwa perempuan mempunyai identitas yang lemah. Perempuan dapat memiliki pilihan dan keinginan untuk mengeksplor dirinya sebagaimana yang ia mau. Melalui tokoh Shakuntala, ia ikut memberikan perbedaan dan mengkonstruksi ulang cara berpikir masyarakat yang menjadikan perempuan objek dengan melekatkan identitas yang mereka berikan, tanpa individu itu sendiri yang bebas menentukannya.

Di dalam novel terlihat juga perbedaan yang nampak pada tokoh Yasmin. Kehadirannya mengubah perspektif mengenai perempuan penyelingkuh. Tidak selamanya perempuan yang diselingkuhi, namun bisa terjadi sebaliknya. Peristiwa ini tergambar saat Yasmin tidak malu dan takut untuk berselingkuh dengan Saman, meskipun ia sudah bersuami. Perbedaan ini sangat jelas terlihat antara Yasmin dengan perempuan pada umumnya.

Lihatlah Yasmin. Dia masih tega menasehati aku, seolah dia lebih bemoral ketimbang aku. Padahal, detik ini juga dia tengah merencanakan perselingkuhan dengan Saman. Sembilan hari lagi kami akan berangkat ke New York. Tiket, dokumen travel, segala jadwal telah beres (Utami, 2017:101).

Secara eksplisit pembaca akan menilai bahwa tokoh Yasmin sangat jahat kepada suaminya. Sudah memiliki kehidupan yang mapan dan enak tetap saja tidak puas, sehingga berselingkuh. Bila kita melihat secara umum seringkali perempuanlah yang diselingkuhi di dalam rumah tangga. Hal ini sering terdengar dan dianggap biasa 


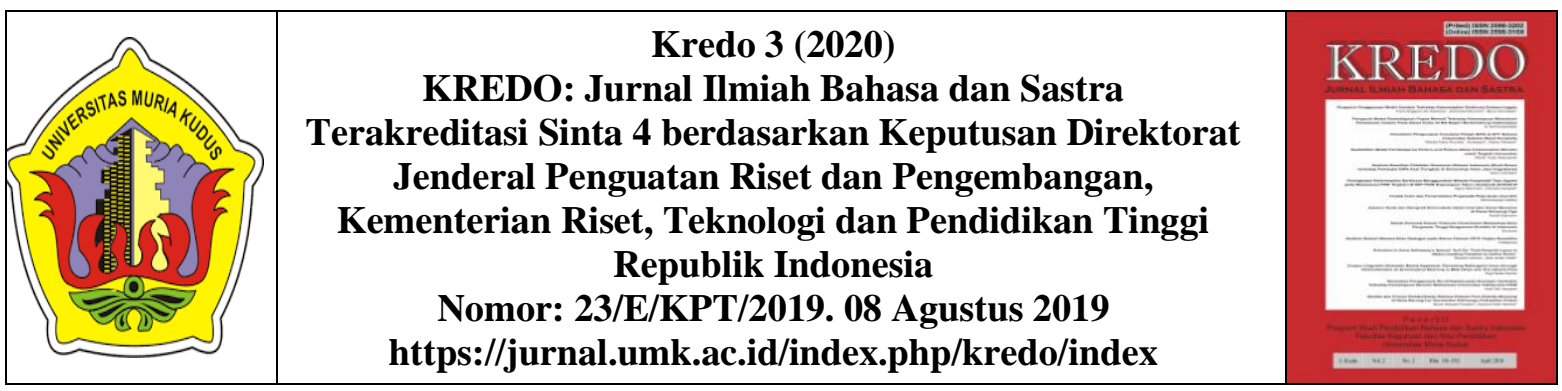

di dalam masyarakat. Bahkan ada kecenderungan perempuan yang disalahkan, karena tidak bisa membahagiakan suaminya. Dengan membalikan apa yang ada di masyarakat, tokoh di dalam cerita ini menyadarkan pembaca maupun masyarakat bahwa perempuan memiliki keinginan dan kesempatan yang sama dengan laki-laki. Oleh sebab itu, representasi tokoh perempuan penyelingkuh ini sebagai kritik terhadap ketidakadilan yang seringkali perempuan alami, baik dirinya diselingkuhi ataupun menyelingkuhi perempuan akan tetap disalahkan. Tokoh Yasmin di dalam cerita juga mengeritisi bahwa masih banyak perempuan yang senang disakiti melalui berbagai sistem di dalam masyarakat. Dengan demikian terlihat bahwa Yasmin ingin menjadi perempuan yang berbeda sesuai dengan keinginannya dan bukan karena orang lain.

Wanita menyelamatkan diri dengan mengambil ke dalam dirinya dominasi pria (sebagaimana yang dikukuhkan banyak agama) dan menganggapnya agung. Karena itu, aku katakan, sembilan puluh persen wanita di dunia ini adalah masokis (Utami, 2017:180).

Selain penggambaran dari beberapa tokoh perempuan. Di dalam novel Larung juga menceritakan sosok mantan Presiden Megawati. Latar dari cerita ini masih berada pada masa-masa Orde Baru. Di mana ketika itu ada permasalahan yang terjadi dengan pemerintahan dengan partai yang dipimpin oleh Megawati. Sebagaimana yang kita ketahui setelah masa Orde Baru, yakni masa Reformasi, Megawati adalah Presiden pertama perempuan di Indonesia. Penggambaran terhadap presiden Megawati menjadi salah satu contoh rill bahwa perempuan dapat bebas menentukan pilihannya.

Nama Megawati Sukarnoputri mulai muncul sebagai simbol perlawanan terhadap Soeharto sejak ia secara de facto menjadi ketua umum partai dalam musyawarah nasional luar biasa di Surabaya, yang disahkan Kongres III di Kemang, Jakarta, tahun 1993. Sejak itu wanita pendiam ini berpotensi menjadi ancaman bagi Soeharto dalam Pemilu 1997 mendatang (Utami, 2017:200).

Penggalan cerita di atas, bila kita baca sekilas maka kita akan terlihat cerita tersebut hanya menjadi representasi akan perlawanan pemerintahan di masa lalu. Akan tetapi, sebenarnya bila kita melihat secara implisit. Kita akan mengetahui bahwa pengarang menceritakan Megawati Soekarno Putri bukan hanya menyisaratkan Megawati sebagai simbol perlawanan Soeharto saja, namun ia menjadi simbol perlawanan laki-laki. Dalam hal ini, perempuan juga memiliki kekuasaan dalam segala bidang kehidupan. Megawati menjadi representasi seluruh perempuan yang ada di dunia bahwa perempuan juga mempunyai kesempatan dan kebebasan untuk maju. Salah satunya menjadi seorang pemimpin.

Dengan hadirnya sosok Megawati di dalam cerita membuktikan bahwa identitas perempuan dapat dibangun berdasarkan pilihan dan kebebasan perempuan. Sebab laki-laki maupun perempuan memiliki hak yang sama dalam kehidupan.

\section{SIMPULAN}

Identitas sangat dibutuhkan oleh setiap manusia. Salah satunya perempuan. 


Kredo 3 (2020)
KREDO: Jurnal Ilmiah Bahasa dan Sastra
Terakreditasi Sinta 4 berdasarkan Keputusan Direktorat
Jenderal Penguatan Riset dan Pengembangan,
Kementerian Riset, Teknologi dan Pendidikan Tinggi
Republik Indonesia
Nomor: 23/E/KPT/2019. 08 Agustus 2019
https://jurnal.umk.ac.id/index.php/kredo/index

Melalui identitas, perempuan dapat menentukan dirinya menjadi sesuatu yang ia harapkan. Akan tetapi, dalam prosesnya seringkali perempuan tidak diberikan kesempatan dalam menemukan identitasnya. Hal ini disebabkan dalam masyarakat seringkali identitas dianggap suatu hal yang stabil dan tetap. Dengan demikian, bila terjadi perubahan dan perbedaan identitas pada diri seseorang, maka dianggap sebagai penyimpangan terhadap norma dan nilai yang telah pasti.

Kehadiran tiga tokoh perempuan dalam novel Larung karya Ayu Utami, yaitu Yasmin, Cok, dan Shakuntala telah membuktikan bahwa identitas yang selama ini dianggap tetap ternyata tidak. Ketiganya mengalami perubahan, baik tingkah laku dan pemikiran. Proses perubahan itu terbentuk, karena adanya kesempatan dan kebebasan dalam diri mereka untuk berkembang sesuai keinginan. Dalam pengonstruksian identitas, ternyata tidak hanya berasal dari pendeskripisian pada dirinya saja. Ada pula pengaruh dari masa lalu dan komunitas yang telah mendorong dalam pembentukan identitas mereka.

Perubahan yang dialami juga membawa perbedaan pada diri mereka sebagai perempuan. Meskipun sesama perempuan ternyata mereka memiliki perbedaan masing-masing. Hal ini tidak dapat disalahkan, sebab identitas tidak hanya terdiri dari satu, tetapi ada banyak identitas di dalam diri manusia. Perbedaan ini dilihat dari tindakan mereka yang cenderung berbeda-beda. Ada keinginan untuk memiliki pendidikan, adapula yang mengejar kedudukan pekerjaan, dan kebebasan dalam hubungan seksual.

Proses pembentukan identitas diri, tiga tokoh perempuan ini juga menolak sistem patriarki yang ada di masyarakat.
Anggapan mereka bahwa sistem tersebut hanya membatasi perempuan dalam hal mendeskripsikan dirinya. Perempuan menjadi sulit untuk menentukan identitasnya. Oleh sebab itu, Yasmin, Cok, dan Shakuntala dalam menjalani kehidupan tidak selalu mengikuti norma dan nilai yang hanya merugikan dirinya sebagai perempuan.

Berdasarkan temuan ini membuktikan pula bahwa telah terjadi pergeseran sejak pasca Orde Baru mengenai identitas perempuan. Terdapat gerakan dari kaum Perempuan Indonesia untuk mulai kritis mempertanyakan kedudukannya di tengah masyarakat. Perempuan juga mulai memiliki kesadaran untuk berani dan bebas dalam menentukan kehidupannya, baik dalam pendidikan, pekerjaan, dan rumah tangga.

\section{DAFTAR PUSTAKA}

Barker, Chris. 2009. Cultural Studies. Teori dan Praktik. Diterjemahkan dalam bahasa Indonesia oleh Nurhadi. Yogyakarta: Kreasi Wacana.

Chasanah, Ida Nurul. 2016. Relasi Kuasa

Tubuh dalam Suara-Suara

Perempuan Pengarang Indonesia Mutakhir.

http://repository.unair.ac.id/44390/.

De Beauvoir, Simone. 2016. Second Sex: Mitos dan Fakta. Diterjemahkan dalam bahasa Indonesia oleh Toni B. Febriantono dan Nuraini Juliastuti. Yogyakarta: Narasi.

Echols, John dan Hasan Shadily. 1983. Kamus Inggris Indonesia Cet. ke XII. Jakarta: Gramedia.

Fakih, Mansour. 2016. Analisis Gender dan Transformasi Sosial. Yogyakarta: Insistpress.

Geleuk, Maria Benga. 2017. Perjuangan Tokoh Perempuan dalam Novel 


Kredo 3 (2020)
KREDO: Jurnal Imiah Bahasa dan Sastra
Terakreditasi Sinta 4 berdasarkan Keputusan Direktorat
Jenderal Penguatan Riset dan Pengembangan,
Kementerian Riset, Teknologi dan Pendidikan Tinggi
Republik Indonesia
Nomor: 23/E/KPT/2019. 08 Agustus 2019
https://jurnal.umk.ac.id/index.php/kredo/index

"Tanah Tabu" Karya Anindita S. Thayf: Kajian Feminisme Eksistensialis. Jurnal Ilти Budaya, Vol. 1 No. 3, Edisi Juli 2017, hal. 221-232.

Hall, Stuart. 1990. Cultural Identity and Diaspora In Rutherford. London: Lawrence and Wishart.

Hasyim, Muhammad. 2016. Buku Ajar Mata Kuliah Kajian Budaya dan Media. Departemen Sastra Barat Roman. Fakultas Sastra, Universitas Hasanuddin.

Hellwig, Tineke. 2003. In The Shadow of Change: Citra Perempuan dalam Sastra Indonesia. Depok: Desantara.

Liliweri, Alo. 2018. Prasangka, Konflik, dan Komunikasi Antarbudaya. Jakarta: Prenada Media.

Morissan. 2015. Teori Komunikasi Individu hingga Massa. Jakarta: Prenada Media.

Prakoso, Teguh dan Venus Khasanah. 2009. Karya Sastra Perempuan: Analisis Awal tentang Perang Gender. Atavisme, Vol.12 No.1 Edisi Juni 2009, hal.77-82.

Purwanti, Yuni. 2009. Novel Saman dan Larung Karya Ayu Utami dalam Perspektif Gender. Tesis. Solo:
Program

Universitas Sebelas Maret.

Puspitawati, Herien. 2013. Konsep, Teori, dan Analisis Gender. Bogor: IPB Press.

Rengganis, Riries dan Rachmat Djoko Pradopo. 2005. Saman dan Larung: Seksualitas Perempuan dalam Karya Sastra. Jurnal Humanika, Vol.18 No.4 Edisi Oktober 2005.

Rokhmansyah, Alfian. 2014. Studi dan Pengkajian Sastra: Perkenalan terhadap Ilmu Sastra. Yogyakarta: Graha Ilmu.

2016. Pengantar Gender dan Feminisme: Pemahaman Awal Kritik Sastra Feminisme. Yogyakarta: Garudhawaca.

Sugihastuti dan Suharto. 2016. Kritik Sastra Feminis: Teori dan Aplikasinya. Yogyakarta: Pustaka Pelajar.

Susanto, Dwi. 2016. Pengkajian Karya Sastra. Yogyakarta: Caps.

Tong, Rosemarie Putnam. 2010. Feminist Thought. Diterjemahkan dalam Bahasa Indonesia oleh Aquarini Priyatna Prabasmoro. Yogyakarta: Jalasutra.

Utami, Ayu. 2017. Larung: Cetakan ke-5. Jakarta: Kepustakaan Populer Gramedia. 